\title{
Interaction of Temperature and Light on Seed Germination in Tecoma stans L. Juss. ex Kunth (Bignoniaceae)
}

\author{
Fábio Socolowski, Daniela Cristine Mascia Vieira and Massanori Takaki* \\ Departamento de Botânica; Universidade Estadual Paulista; C. P.: 19; 13506-900; Rio Claro - São Paulo - Brasil
}

\begin{abstract}
The effects of the temperature and light on the control of seeds germination in Tecoma stans was studied in the present work. The influence of constant temperatures from 10 to $45^{\circ} \mathrm{C}$, with $5^{\circ} \mathrm{C}$ intervals, under the white light and darkness were tested. The optimum temperature for the germination of the seeds was between 25 and $30^{\circ} \mathrm{C}$, for both the light and the dark treatments. The maximal germination was reached in the range of 15 to $35^{\circ} \mathrm{C}$ under the light and of 20 to $40^{\circ} \mathrm{C}$ in the darkness. The seeds showed highest synchronization of the germination near the optimal temperature. The germination in the field was tested under the two light conditions. The highest percent of germination occurred under the direct sunlight (86.1\%) than under the canopy (69\%). However, under the canopy, the seedling presented $1.5 \%$ of the recruitment, while under the direct sunlight, $96.9 \%$. Results showed that T. stans seeds germinated well in the open areas with the occurrence of high seedling recruitment indicating the invasion potential of the species in such light conditions.
\end{abstract}

Key words: Tecoma stans, cardinal temperatures, seed germination, invasion potential

\section{INTRODUCTION}

The temperature and light are the most important environmental factors that promote the seed germination in the soil when water is available. For most of the plants, if the light and water are available, the temperature of the soil determines the fraction of the germinated seeds and the rate of the germination (Andrade, 1995). The germination of the seeds is a complex process where several reactions and individual factors are involved, every process affected by the temperature (Copeland and McDonald, 1995). The temperature affects the germination and the state of dormancy of the seeds and the seasonal changes of the dormancy state of the seeds of some species is directly related to the seasonal temperature changes (Pons, 1993). Some species can present the seeds with the light requirement for the germination at one temperature and in another, the light insensitivity (Smith, 1975).

The formation of the canopy gaps of different sizes in the tropical forest is responsible for the changes of the light environment, leading to the changes in the light quality, temperature and soil humidity (Everham III et al., 1996). The changes in the light environment result in the temperature fluctuations due to the direct sunlight (VásquezYanes and Orosco-Segovia; 1993, Bullock, 2000). Then the gaps present the sites of the specific regeneration, in the border by the shade tolerant species and in the central area by the shade intolerant species (Brown, 1996). The invasion of open areas by the exotic plant species occurs,

*Author for correspondence 
especially by the species with pioneer characteristics, which occupy rapidly the open areas, usually, with decrease of the local biodiversity (Ziller, 2001).

Tecoma stans L. Juss. Ex Kunth. is an arboreousarbutive species probably originated in Mexico (Sandwich and Hunt, 1974), occurring naturally from Florida Southeast and Texas South in the United States of America, in Antilles and Central America until the northeast of Argentina (Gentry, 1992). It occurs in several parts of the tropical America, and is commonly used as the ornamental plant due to its yellow flowers produced during the summer and autumn (Sandwich and Hunt, 1974). In Brazil, it is used as the ornamental plants in the parks, home gardens and urban arborization, but it is considered arbustive weed in the pastures (Lorenzi, 2000; Lorenzi et al., 2003), with vigorous sprouts after trimming (Passini and Kranz, 1997). T. stans produces large quantities of small and anemocoric seeds (Lorenzi, 2000, Lorenzi et al., 2003), with some of characteristics presented by the species with the invasion potential (Ziller, 2001).

Due to the those characteristics and interest in its handling (Passini and Kranz, 1997, Ziller, 2001, Ferreira et al., 2002), the effects of the temperature and light on the germination of the seeds of $T$. stans under the laboratory conditions was analyzed for the determination of the cardinal and optimum temperature and the recruitment potential of the species under the natural conditions.

\section{MATERIAL AND METHODS}

The seeds of T. stans were harvested from 18 plants located at UNESP Campus at Rio Claro, São Paulo, Brasil. After the harvest, the seeds were stored in a sealed glass bottle at $10^{\circ} \mathrm{C}$. All the experiments were carried out for four months. For the germination tests, 25 seeds in four germination plastic boxes (gerbox) with one layer of filter paper imbibed with $10 \mathrm{ml}$ distilled water were used. Different isothermic incubations from 10 to $45^{\circ} \mathrm{C}$ with $5^{\circ} \mathrm{C}$ intervals were done in the germinators (FANEM and MARCONI, São Paulo, Brasil). The seed germination was scored daily and the seeds with $1 \mathrm{~mm}$ long roots were considered as germinated. The dark incubations were obtained by the use of black gerboxes and the germinated seeds scored under the dim green safe light (Amaral-Baroli and Takaki, 2001). White light was obtained with the aid of two $15 \mathrm{~W}$ daylight fluorescent lamps with fluence of $32.85 \mu \mathrm{mol} \cdot \mathrm{m}^{-2} \cdot \mathrm{s}^{-1}$. All the experiments were finished when no germination was observed for five consecutive days.

The field germination tests were carried out under the direct sunlight and under the canopy shade. Four replicates with 24 seeds each were used in each light condition. The seeds were sowed in $27 \mathrm{~mm}$ diameter and $127 \mathrm{~mm}$ long tubes containing the commercial substrate $\left(\right.$ Plantmax $^{\circledR}$, Eucatex, São Paulo, Brasil) at $10 \mathrm{~mm}$ depth. The soil temperature was monitored with the aid of a thermometer inserted in the substrate and daily measurements were made during 30 days. Light spectra under both conditions were obtained with the aid of a LI-1800 spectroradiometer (LI-COR, U.S.A.). Watering was done every day and the seeds were considered as germinated when the cotyledons were totally expanded out of the substrate. The rate of the recruitment was determined by calculating the percentage of emerged seedling after 30 days from the sowing. The germination percentage and rate, relative frequency of seed germination and synchronization indexes were calculated according to Labouriau (1983). Since the germination data presented no homogeneity and normality, the percentage and germination and synchronization indexes and the temperature effects were analyzed by Kruskal-Wallis test (ANOVA by ranks) and by Nemenyi test at $\alpha=0.05$. The effect of the light and darkness by each temperature was compared by Mann-Whitney test at $\alpha=0.05$. and the field germination experiment by $\mathrm{t}$ test (Zar, 1999).

\section{RESULTS AND DISCUSSION}

Seeds of $T$. stans germinated in the range of 15 to $40^{\circ} \mathrm{C}$, while under 10 and $45^{\circ} \mathrm{C}$ no germination under the light and darkness was observed (Fig. 1). The minimum temperature was between 10 and $15^{\circ} \mathrm{C}$ and the maximum between 40 and $45^{\circ} \mathrm{C}$, under the light and darkness (Labouriau, 1983). 


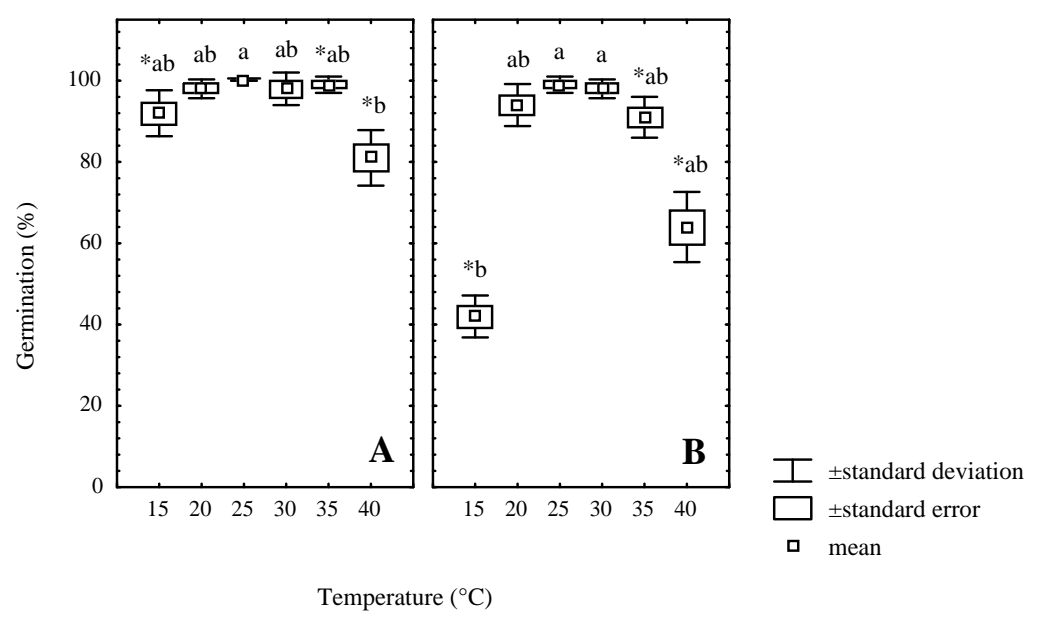

Figure 1 - Germination percentage of seeds of Tecoma stans at different temperatures, under white light (A) and darkness (B). Means followed by the same letter inside each treatment of light and darkness are not significantly different by Nemenyi test $(\alpha=0.05)$. * indicates significantly differences by Mann-Whitney test $(\mathrm{p}=0.05)$ between light and darkness treatments for each temperature.

Under the low temperatures the metabolic activities was relatively low and responses could not be observed in the plants (Okusanya, 1980). On the other hand, high temperatures for long periods could induce protein denaturations. The cardinal temperatures of the seed germination reflected the conditions that led to rapid development of their seedlings. The species with large distribution present broad range of temperature for the seeds germinate (Larcher, 2000). However, Santos et al. (2005) observed that the seeds of Tabebuia chrysotricha Mart. Ex DC.) Standl, with large distribution presented minor temperature range than the seeds of $T$. serratifolia (Vahl) Nich and T. roseo-alba (Ridl.) Sand with the restricted distribution. The seeds of $T$. stans presented high germination at $25^{\circ} \mathrm{C}$, although with no significant differences in the range of temperatures of 15 and $35^{\circ} \mathrm{C}$ for the light incubation and 20 to $40^{\circ} \mathrm{C}$ under the darkness. At 15 and $40^{\circ} \mathrm{C}$ the germination of the seeds of $T$. stans was affected by the light, as reported by Smith (1975) in the seeds of Lactuca sativa L. cv. Grand rapids, where the light sensitivity was dependent on the temperature of incubation. At low temperatures, lettuce seeds were light insensitive; the intermediary temperatures were photosensitive and presented thermodormancy at high temperatures.
Cabral et al. (2003) observed that the seeds of $T$. aurea (Manso) Benth. and Hook F. ex. Moore presented the highest percentage germination at the range of 20 to $40^{\circ} \mathrm{C}$ in the absence of the light. The seeds of Jacaranda mimosifolia (D. Don.), another Bignoniaceae, germinated under both light and darkness, under the same range of 20 to $40^{\circ} \mathrm{C}$ (Socolowski and Takaki, 2004). But, under the water stress conditions, germinated only under white light. The germination rate was also affected by the temperature, being highest at $30^{\circ} \mathrm{C}$, demonstrating that the optimum temperature was between 25 and $30^{\circ} \mathrm{C}$, under the light and darkness (Fig. 2).

Santos et al. (2005) observed that the optimum temperature for the germination of seeds of some Bignoniaceae ( $T$. chrysotricha, $T$. serratifolia and T. roseo-alba) was in the range of 20 to $30^{\circ} \mathrm{C}$. At $15^{\circ} \mathrm{C}$ although the low germination rate in $T$. stans, the final percentage germination did not differed from results obtained at 20 to $35^{\circ} \mathrm{C}$. Although the highest percentage and the rate of the germination at 25 to $30^{\circ} \mathrm{C}$, indicating the optimum range of the temperature, it was observed that the homogeneity of the distribution of the polygon of relative germination frequency was between 25 to $40^{\circ} \mathrm{C}$ under the light, and between 20 to $30^{\circ} \mathrm{C}$ in the darkness (Fig. 3). 


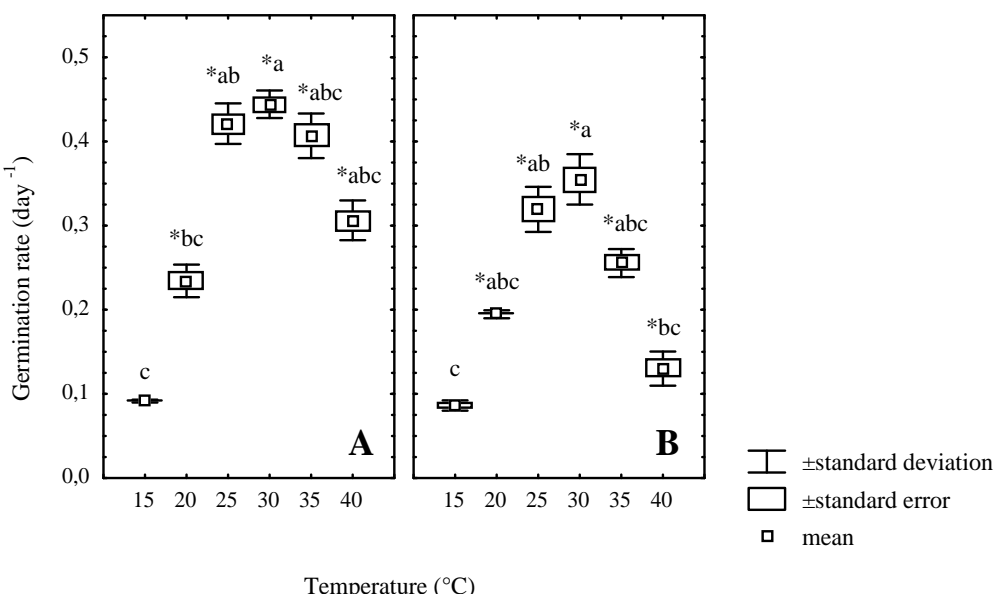

Figure 2 - Germination rate of seeds of Tecoma stans at different temperatures, under white light (A) and darkness (B). Means followed by the same letter inside each treatment of light and darkness are not significantly different by Nemenyi test $(\mathrm{p}=0.05)$. * indicates significantly differences by Mann-Whitney test $(\mathrm{p}=0.05)$ between light and darkness treatments for each temperature.

The highest synchronization of the germination was observed at $30^{\circ} \mathrm{C}$ under the light and at $25^{\circ} \mathrm{C}$ in the darkness, showing the lowest values of the synchronization index (U), which means the highest synchronization at the optimum temperature (Table 1). Generally, at the optimum temperature the polygon of relative frequency of the germination shows the unimodal distribution
(Ferraz-Grande and Takaki, 2001). Asynchronous germination was observed below and above the optimum temperature (Table 1). The asynchronous germination was important for the maintenance of the soil seed bank (Garwood, 1989), showing the physiological heterogeneity of the seeds under the stress temperatures (Labouriau and Agudo, 1987).

Table 1 - Synchronization Index (U) of seed germination in Tecoma stans under white light and darkness.

\begin{tabular}{|c|c|c|c|c|}
\hline \multirow{3}{*}{$\begin{array}{c}\text { Temperature }\left({ }^{\circ} \mathbf{C}\right) \\
15\end{array}$} & \multicolumn{4}{|c|}{$\mathrm{U}$ (bits) $^{1}$} \\
\hline & \multicolumn{2}{|c|}{ Light } & \multicolumn{2}{|c|}{ Darkness } \\
\hline & 2,899 & $\mathrm{~b}$ & 2,967 & $\mathrm{~b}$ \\
\hline 20 & 1,533 & $a b^{*}$ & 2,182 & $a b^{*}$ \\
\hline 25 & 0,928 & $a^{*}$ & 1,389 & $a^{*}$ \\
\hline 30 & 0,796 & $a^{*}$ & 1,596 & $a^{*}$ \\
\hline 35 & 1,194 & $a b^{*}$ & 2,181 & $a b^{*}$ \\
\hline 40 & 1,733 & $a b^{*}$ & 2,873 & $b^{*}$ \\
\hline
\end{tabular}

${ }^{1}$ Means followed by the same letter inside each treatment of light and darkness are not significantly different by Kruskal-Wallis test $(\mathrm{p}=0.05)$.

* indicates significantly differences by Mann-Whitney test $(\mathrm{p}=0.05)$ between light and darkness treatments for each temperature. 


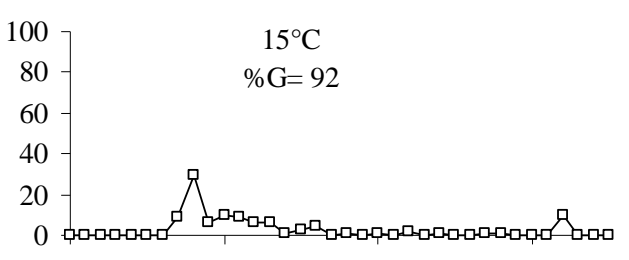

$0 \quad 10$

20

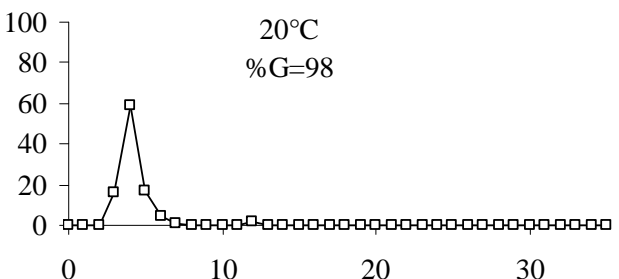

$$
0
$$

10

$25^{\circ} \mathrm{C}$

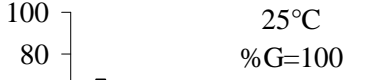

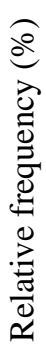
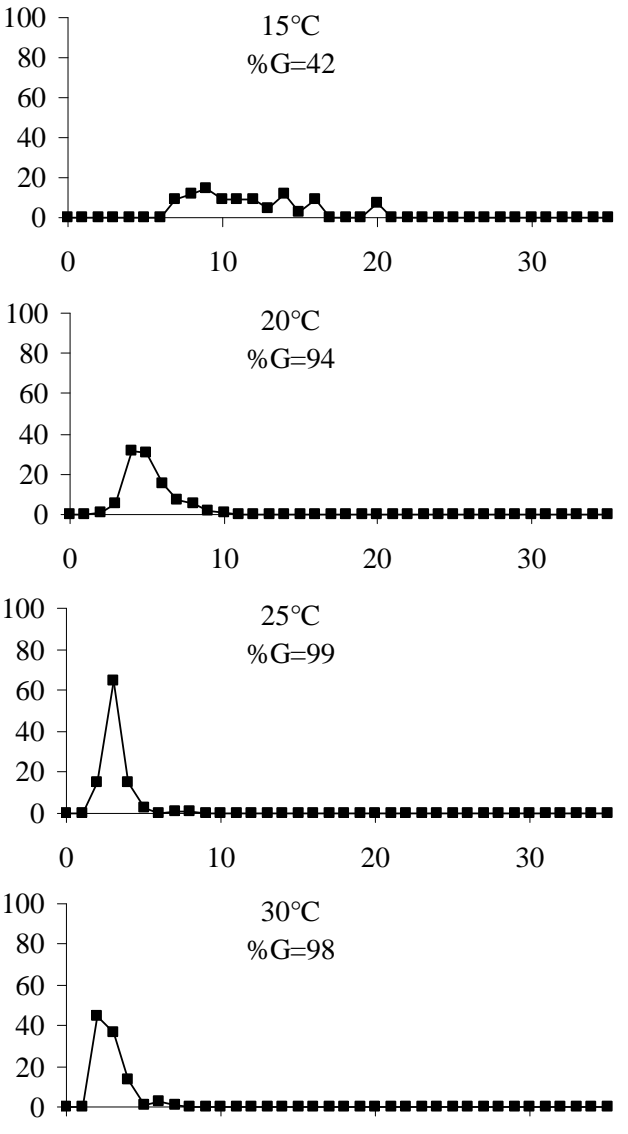

0

10

20

30
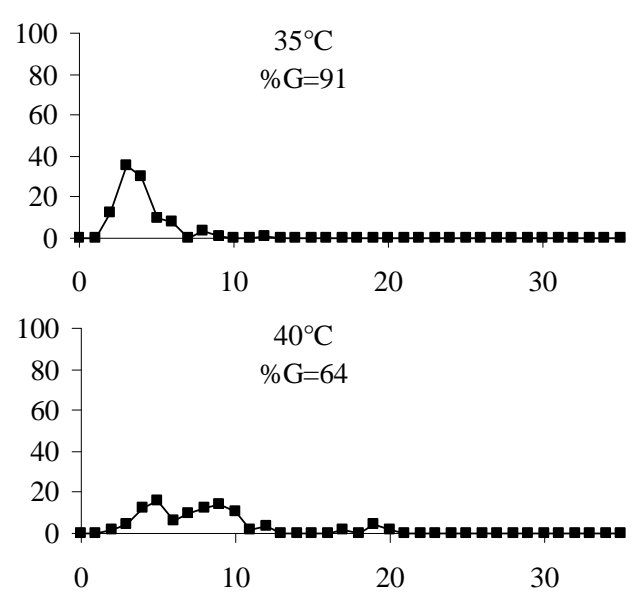

Days from sowing

Figure 3 - Distribution of polygon of relative frequency of germination of seeds of Tecoma stans under different temperatures and under white light $(\square)$ and darkness (๘). Final percentage germination is represented by $\% \mathrm{G}$. 

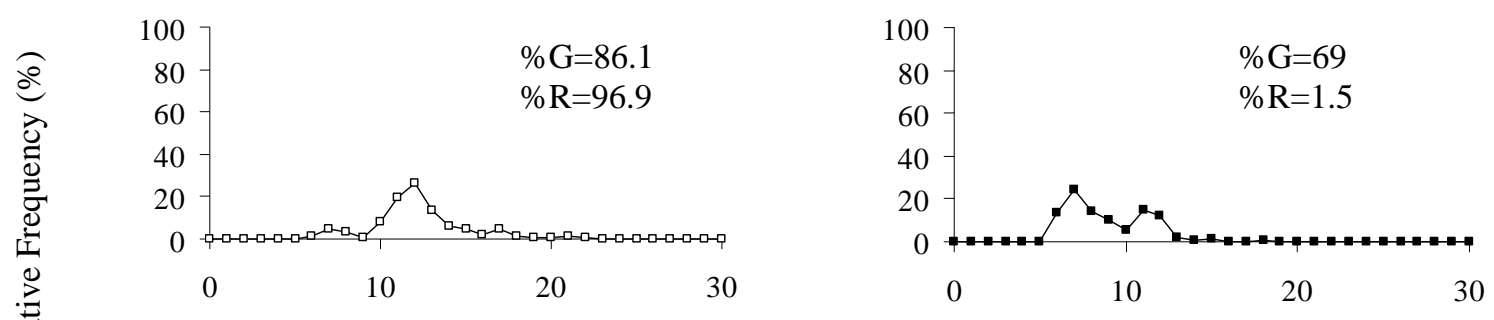

Days from sowing

Figure 4 - Distribution of relative frequency of seed germination in Tecoma stans under the direct sunlight $(\square)$ and shade of canopy $(\mathbf{\square})$. $\% \mathrm{G}=$ percentage germination and $\% \mathrm{R}=$ percentage recruitment.

The germination of the seeds of T. stans in the field revealed that under direct sunlight, $86.1 \%$ seeds germinated but under the canopy, only $69 \%$. The rate of the germination was highest under the canopy $\left(0.11\right.$. day $\left.^{-1}\right)$ than under the direct sunlight $\left(0.08\right.$. day $\left.^{-1}\right)$. The distribution of the polygon of the relative frequency of the seed germination showed the heterogeneity of the germination (Fig. 4) with the same synchronization indexes ( 2.46 bits under the canopy and 2.53 bits under the direct sunlight). The spectral distribution of the direct and the canopy filtered sunlight (Fig. 5) indicated the differences in the total fluences $(238 \mu$ mol.m ${ }^{2} . \mathrm{nm}^{-1} . \mathrm{s}^{-1}$ for the direct sunlight and $5.26 \mu \mathrm{mol} . \mathrm{m}^{-}$ ${ }^{2} \cdot \mathrm{nm}^{-1} \cdot \mathrm{s}^{-1}$ for the shade light) and Red:Far red ratios (1.26 for the direct sunlight and 0.12 for the shade light). Although Red:Far red ratio is important for the detection of the shade by the plants through the phytochrome (Smith, 2000), light environments had no effect on the seed germination of T. stans, confirming the data obtained under the laboratory conditions.

The daily maximum temperature of the substrate under the direct sunlight was $10^{\circ} \mathrm{C}$ higher than under canopy, although the minimum temperatures were the same. Thus, under the direct sunlight the range of the temperature was $16^{\circ} \mathrm{C}$ while under the canopy it was $6^{\circ} \mathrm{C}$. The highest germination rate under the canopy indicated that the lowest thermal stability under the direct sunlight could decrease the water availability (Vázquez-Yanes et al., 1990), and as reported by Cordero and Di Stéfano (1991), the germination rate of the seeds of $T$. stans was decreased by the low water potential.

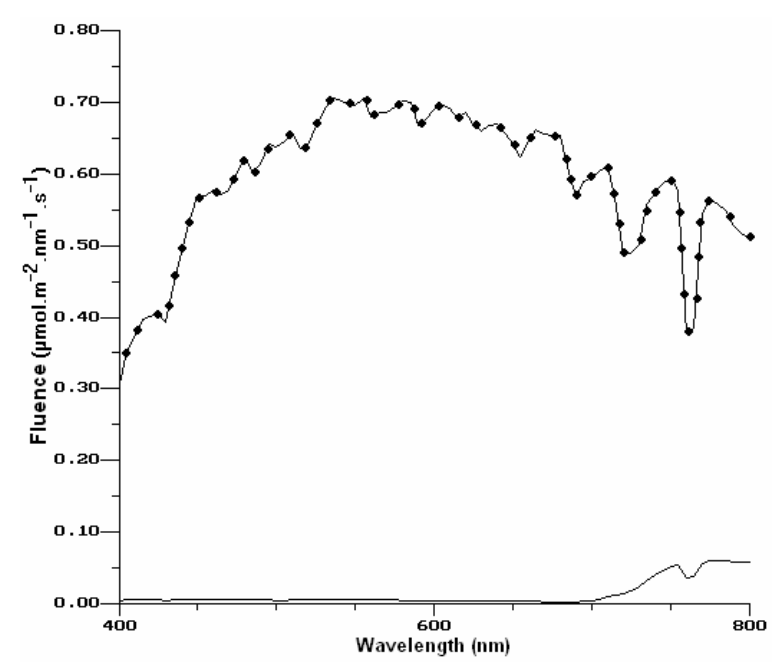

Figure 5 - Spectral distribution of the direct sunlight (-•-) and shade light (-). 
In the natural conditions the recruitment of the plants of $T$. stans with more that $50 \mathrm{~cm}$ height and diameter at the breath height $(\mathrm{DBH})$ larger than $3 \mathrm{~cm}$, was observed only in open areas with 3 to 4 year-old. Ten to twelve year-old plants with the $\mathrm{DBH}$ higher that $10 \mathrm{~cm}$ were found in the abandoned cultivation areas in high density and disappeared in the mature forest when 20 to 45 year-old (Grau et al., 1997).

The present results showed that although the seeds of $T$. stans germinated under the direct sunlight conditions and under the canopy, the rate of the recruitments was $96.9 \%$ and $1.5 \%$, respectively. The same happened with Jacaranda copaia (Aubl.) D. Don, whose plants needed the sunlight for full development (Campos and Uchida, 2002). Usually exotic plants with the invader potential are shade intolerant and rarely occupy the environments with low light availability in the tropical forests (Fine, 2002).

The present work indicated that the seeds of $T$. stans germinate in a wide range of temperature and in the field under the direct sunlight as well under the shade. However, the effective recruitments occured only in the open areas as the pasture, large gaps and forest borders. These results summed to the fact that $T$. stans produces large amount of anemocoric seeds which is widely dispersed (Vieira, 2004) and the rapid seedling development under the sunlight (Souza et al., 2001) confirmed the aggressiveness of the species and consequently showed its invader potential. This becomes important since the species is currently used as the ornamental plant due to its yellow flowers and by the confusion made by some authors who considered T. stans as a native species and recommended it in Brazilian forest restoration programs (Souza et al., 2001).

\section{RESUMO}

Os efeitos da temperatura e da luz na germinação de Tecoma stans foram determinados no presente trabalho. Foram testadas temperaturas constantes de 10 a $45^{\circ} \mathrm{C}$, com intervalos de $5^{\circ} \mathrm{C}$, sob luz branca e escuro. Verificou-se que a temperatura ótima para a germinação da espécie está entre 25 e $30^{\circ} \mathrm{C}$, tanto na luz como no escuro, já o intervalo de máxima germinabilidade está entre 15 e $35^{\circ} \mathrm{C}$ na luz e 20 e $40^{\circ} \mathrm{C}$ no escuro. Suas sementes apresentaram uma maior sincronização da germinação próxima à temperatura ótima. A germinação de sementes de Tecoma stans em condições naturais foi testada sob radiação solar direta e na sombra de vegetação. A maior porcentagem de emergência ocorreu no ambiente de sol $(86,1 \%)$, porém com menor velocidade em relação à sombra, embora na sombra também ocorreu a emergência, mas em menor proporção (69\%). Entretanto, o índice de recrutamento na sombra foi de $1,5 \%$ enquanto a pleno sol foi de $96,9 \%$. Estes resultados indicam que as sementes de Tecoma stans germinam e recrutam suas plântulas em ambientes abertos confirmando o potencial invasor da espécie.

\section{ACKNOWLEDGEMENTS}

The authors are grateful to $\mathrm{CNPq}$ for the fellowships. This work was supported by the grants from the CNPq, FAPESP and FUNDUNESP.

\section{REFERENCES}

Amaral-Baroli, A. and Takaki, M. (2001) Phytochrome controls achene germination in Bidens pilosa L. (Asteraceae) by very low fluence response. Brazilian Archives of Biology and Technology, 44, 121-124.

Andrade, A.C.S. (1995). Efeito da luz e da temperatura na germinação de Leandra breviflora Cong., Tibouchina benthamiana Cong., Tibouchina grandifolia Cong. e Tibouchina moricandiana (DC.) Baill. (Melastomataceae). Revista Brasileira de Sementes, 17, 29-35.

Brown, N. A (1996). Gradient of seedling growth from the center of a tropical rain forest canopy gap. Forest Ecology and Management, 82, 239-244.

Bullock, J.M. (2000). Gaps and seedling colonization. In: Fenner, M. (Ed.) Seeds: The ecology of seeds regeneration in plant communities. Trowbridge: CABI, pp. 375-395.

Cabral, E.L.; Barbosa, D.C.A. and Simabukuro, E.A. (2003). Armazenamento e germinação de sementes de Tabebuia aurea (Manso) Benth. and Hook. F. ex. S. Moore. Acta Botanica Brasílica, 17, 609-617.

Campos, M.A.A. and Uchida, T. (2002). Influência do sombreamento no crescimento de mudas de três espécies amazônicas. Pesquisa Agropecuária Brasileira, 37, 281-288.

Cordero, S. R.A. and Di Stéfano, G.J.F. (1991) Efecto del estrés osmótico sobre la germinación de semillas de Tecoma stans (Bignoniaceae). Revista de Biología Tropical, 39, 107-110. 
Copeland, L.O. and McDonald, M.B. (1995). Principles of seed science and technology. New York: Chapman and Hall, pp. 409.

Everham III, E.M.; Myster, R.W. and VanDegenachte, E. (1996). Effects of light, moisture, temperature, and litter on the regeneration of five tree species in the tropical montane wet forest of Puerto Rico. American Journal of Botany, 83, 1063-1068.

Ferraz-Grande, F.G.A. and Takaki, M. (2001). Temperature dependent seed germination of Dalbergia nigra Allem (Leguminosae). Brazilian Archives of Biology and Technology, 44, 401-404.

Ferreira, B.G.A.; Pedrosa-Macedo, J.H.; Bredow, E.A.and Vitorino, M.D. (2002). Ipê-mirim Tecoma stans (L.) Kunth (Bignoniaceae) - um paradoxo nacional? In: Simpósio Nacional sobre Recuperação de Áreas Degradadas, 5, Belo Horizonte. Anais Belo Horizonte: SOBRADE, pp.144-146.

Fine, P.V.A. (2002). The invasibility of tropical forests by exotic plants. Journal of Tropical Ecology, 18, 687-705.

Garwood, N.C. (1989). Tropical soil seed banks: a review. In: Leck, M.A.; Parker, V.T.; Simpson, R.L. (Eds.). Ecology of soil seed banks. London: Academic Press, pp.149-209.

Gentry, A.H. (1992). Bignoniaceae. Flora Neotropica, New York, pt. 2, 370.

Grau, H.R.; Arturi, M.F.; Brown, A.D. and Aceñolaza, P.G. (1997). Floristic and structural patterns along a chronosequence of secondary forest succession in Argentinean subtropical montane forests. Forest Ecology and Management, 95, 161-171.

Labouriau, L.G. (1983). A germinação das sementes. Washington: Secretaria-Geral da OEA, pp. 174.

Labouriau, L.G. and Agudo, M. (1987). On the physiology of seed germination in Salvia hispanica L. I. Temperature effects. Anais da Academia Brasileira de Ciências, 59, 37-56.

Larcher, L. (2000). Ecofisiologia vegetal. São Carlos: RiMa, pp. 531.

Lorenzi, H. (2000). Plantas daninhas do Brasil: terrestres, aquáticas, parasitas e tóxicas. 3 ed. Nova Odessa: Plantarum, pp. 608.

Lorenzi, H.; Souza, H.M.; Torres, M.A.V. and Bacher, L.B. (2003). Árvores exóticas no Brasil: madeireiras, ornamentais e aromáticas. Nova Odessa: Plantarum, pp. 368.

Okuzanya, O.T. (1980). Germination and growth of Celosia cristata L., under light and temperature regimes. American Journal of Botany, 67, 854-858.

Passini, T. and Kranz, W. (1997). Eficácia de herbicidas no controle de amarelinho (Tecoma stans) em pastagem. Planta Daninha, 15, 190-197.

Pons, T.L. (1993). Seed responses to light. In: Fenner, M. (Ed.). Seeds: The ecology of regeneration in plant communities. New York: CAB International, pp.259284.
Sandwich, N.Y. and Hunt, D.R. (1974). Bignoniáceas. Flora Ilustrada Catarinense, Itajaí, pt. 1, 172.

Santos, D.L.; Sugahara, V.Y. and Takaki, M. (2005). Efeitos da luz e da temperatura na germinação de sementes de Tabebuia serratifolia (Vahl) Nich, Tabebuia chrysotricha Mart. Ex DC.) Standl. e Tabebuia roseo-alba (Ridl.) Sand - Bignoniaceae. Ciencia Florestal, 15, 87-92.

Smith, H. (1975). Phytochrome and Photomorphogenesis: an introduction to the photocontrol of plant development. London: Mc Graw Hill Company, pp. 235.

Smith, H. (2000). Phytochrome and light signal perception by plants - an emerging synthesis. Nature, 407, 585-591.

Socolowski, F. and Takaki, M. (2004). Germination of Jacarada mimosifolia (D. Don-Bignoniaceae) seeds: effects of light, temperature and water stress. Brazilian Archives of Biology and Technology,47, 785-792.

Souza, P.A.; Venturin, N.; Macedo, R.L.G.; Alvarenga, M.I.N. and Silva, V.F. (2001). Estabelecimento de espécies arbóreas em recuperação de área degradada pela extração de areia. Cerne, 7, 43-52.

Vázquez-Yanes, C. and Orozco-Segovia A. (1993). Patterns of seed longevity and germination in the tropical rainforest. Annual Review of Ecology and Systematics, 24, 69-87.

Vázquez-Yanes, C.; Orozco-Segovia, A.; Rincón, E. and Sánchez-Coronado, M. E. (1990). Light beneath the litter in a tropical forest: effect on seed germination. Ecology, 71, 1952-1958.

Vieira, D.C.M. (2004). Chuva de sementes, banco de sementes e regeneração natural sob três espécies de início de sucessão em uma área restaurada em Iracemápolis (SP). 87p. Dissertação (Mestrado) Escola Superior de Agricultura "Luis de Queiroz", Universidade de São Paulo, Piracicaba.

Zar, J.H. (1999). Biostatistical analysis. 4.ed. New Jersey: Prentice Hall, pp. 929.

Ziller, S.R. (2001). Plantas exóticas invasoras: a ameaça da contaminação biológica. Ciência Hoje, 30, 77-79.

Received: August 03, 2005; Revised: December 07, 2006; Accepted: March 14, 2008. 